Petrova L.G. Moiseenko O.A.

\section{INNOVATIONS IN FOREIGN (CHINESE) STUDENTS' GRAMMAR COMPETENCE FORMATION WHILE TRAINING THEM RUSSIAN AS A FOREIGN LANGUAGE: NETWORK TECHNOLOGY AND THE MODULE APPROACH}

1) $\mathrm{PhD}$ in Pedagogical Sciences, Associate Professor, Department of the Russian Language and Intercultural Communication Belgorod State National Research University, 85 Pobedy St., Belgorod, 308015, Russia; E-mail: petrovali@mail.ru 2) $\mathrm{PhD}$ in Pedagogical Sciences, Associate Professor of the Department of Foreign Languages Belgorod State National Research University, 14-1 Studencheskaya St., Belgorod, 308007, Russia; E-mail: olgaa0102@rambler.ru

\begin{abstract}
The article deals with the researches in the field of finding new methods of teaching Russian to foreign (Chinese) students and its Grammar aspect, in particular. In this connection the authors share the results of the investigation dealt with the development of one of the most future-oriented approaches in methods of training the Russian Grammar standards which may be called the Module Approach realized by means of Network Technologies.

Keywords: Russian as a Foreign Language; Chinese students; methods of teaching; grammar competence; Network Technology; Modules

ИННОВАЦИИ В ОБУЧЕНИИ РКИ ПРИ ФОРМИРОВАНИИ ГРАММАТИЧЕСКОЙ КОМПЕТЕНТНОСТИ ИНОСТРАННЫХ (КИТАЙСКИХ) СТУДЕНТОВ: СЕТЕВАЯ ТЕХНОЛОГИЯ И МОДУЛЬНЫЙ ПОДХОД
\end{abstract}

Петрова Л.Г.

Моисеенко О.А.

1) кандидат педагогических наук, профессор кафедры русского языка и межкультурной коммуникации Белгородский государственный национальный исследовательский университет, ул. Победы, 85, г. Белгород, 308015, Россия; E-mail: petrovali@mail.ru

2) кандидат педагогических наук, доцент кафедры иностранных языков. Белгородский государственный национальный исследовательский университет, ул. Студенческая, 14, г. Белгород, 308007, Россия; E-mail: olgaa0102@ rambler.ru

\begin{abstract}
Аннотация
Стать посвящена исследованию новых подходов к обучению русскому языку иностранных (китайских) студентов, в частности, формированию у них грамматической компетенции. Авторы приводят результаты апробации модульного подхода на основе сетевых технологий к формированию русскоязычных грамматических навыков у иностранцев.
\end{abstract}

Ключевые слова: русский язык как иностранный, китайские студенты, методы обучения, грамматическая компетенция, сетевые технологии, модули.

Introduction: A rapid development of new technologies penetrating into all spheres of our life including education is an essential feature of the $21^{\text {st }}$ century which cannot be neglected. The growing market of educational services and high requirements to their quality force us to new scientific researches. This issue follows the ideas of Russian and foreign researchers such as V. N. Afonasova, G. A. Anisimov, R. S. Bekirova, E.A. Bystrova, V. N. Wagner, V. G. Gak, M.L. Goldschmidt, T.K. Donskaya, I.B. Ignatova, Z.N. Iyevleva,
D. I. Izarenkov, O. A. Moiseenko, V. I. Ostapenko, L.G. Petrova, T.N. Protasova, K.A. Rogova, G. I. Rozhkova, J.D. Russel, S.F. Shatilov, A.N. Schukin, P. A. Yutsyavichene, etc. They are aimed at studying, developing, creation and using new approaches and innovative technologies while teaching Russian to foreigners on the whole and its Grammar aspect, in particular.

The relevance and novelty of the problem under investigation is in the approach itself. It forms the basis for the creation of a principally new system 
of a quality estimation of knowledge, skills and habits in the process of studying the material.

The aim of our research is to describe the advantages of the module approach to teaching foreign (Chineese) students different ways of expressing purpose relations in the Russian language by means of informatics technologies.

Methods: A number of differerent methods in our study. Analytical method helped us in analysis of linguistic, psychological, pedagogical, methodical and technical literature. Supervision over independent educational cognitive activity of students allowed us to generalize experience of training Russian purpose-costructions. The comparative method of theoretical concepts and their practical realization allowed us to develop a modular technique of training of foreign students in ways of expression of the purpose relations.

Main part: Being a material basis of a language, Grammar aspect has always been in the focus of teaching students any foreign language. In the recent years the number of Chinese students getting their education in Russian both in China and in Russia has considerably increased. That's why training foreign ( Chinese) students Russian Grammar standards is one of the up-to-date problems in modern theory and practice of teaching Russian as a Foreign Language.

It should be noted that traditional methods and approaches are still predominant in the system of training Chinese students the Russian Language, and Informatics Technologies are not given much attention to.

In this connection, one of the most prospective approaches in methods of training Russian Grammar standards we are now developing may be called the Module Approach to teaching foreign students different ways of expressing purpose relations in the Russian language realized by means of Network Technologies. It is regarded as a perspective approach in methods of teaching Russian as a foreign language combining both the elements of the classical approach and the new forms of education.

The purpose relations are very important for speakers as they define the purpose of action, desirable events or the phenomena of reality. The communicative importance of the purpose relations is out of question and their wide circulation in all styles of modern Russian testifies to it.

The Russian language has developed a branched system of ways of their expression

Application of the Module Approach allows to structure and order this system.
The main characteristics of the Module Approach to training Russian Grammar standards in this aspect are as follows:

1). Division of the studying Grammar material into completed Sub modules for convenience;

2). Possibility of permanent improving of a Module without changing of its whole structure;

3 ). Individualization of the process of training within the Module due to the set of methodical instruments; student;

4). Independence of a cognitive activity of a

5). Achievement of the aim of training within the Module due to student's comprehension of a practical importance and prospective of his/her activity.

Using of Network Technology as a basis for a foreign students grammar competence formation while training them Russian as a Foreign Language by means of the Module Approach promotes convenient interaction between a student and a tutor; creates conditions for interactive education and automatic estimation of results so that the process of studying becomes more qualitative and enthusiastic.

Practical and controlling blocks of the module which are specially developed for training Russian grammar serve as the integral components of process of management of independent educational activity of students in the informational educational environment and give the chance to trace achievements of the foreign students.

The Module Approach, methods and the content of the course are developed in such a way that the students could be engaged in it independently without excess tension in convenient out-of-class time and at convenient speed. The teacher promotes a motivation of independent work, provides its rational and productive course. The students acquire a training material in the context of the independent solution of communicative and cogitative tasks, and then systematize it.

While making the experiment with foreign students we could research the Module Approach to training Russian Grammar standards in Integrated Educational Environment which is based on Program Cover named "PEGAS". As a result we could come to the following conclusions.

1. The Module Approach to step-by-step training foreign students to Russian Grammar standards by means of Network Technology is grounded for the first time in Methods of Teaching Russian as a Foreign Language providing for the completeness and non-stop character of the training process; check 
up of knowledge mastering and their cognitive activity.

2. The procedure of creation of linguamethodical interactive model of training foreign students Russian Grammar standards by means of Network Technology is well developed. The elaborated model is inculcated in the educational process.

3. These are found and practically realized some methodical ways which develop student's independence in improving his/her skills and habits in Russian speech. The methodical way of imitated educational dialogue between a student and a tutor is recognized as the main one.

4. On the basis of abovementioned data it is elaborated and checked up the model of how to manage the independent cognitive student's activity in the training process by means of Network Technology.

5. The process of training Russian Grammar standards within the Modules is organized on the three main principles: individualization, differentiation, interaction. The students firstly interpret the studying Grammar material and then systematize it independently while solving communicative and mental tasks.

To sum up, the elaborated lingua-methodical interactive model of training foreign students Russian Grammar standards is intended for independent foreign language learning. Every module has three blocks - theoretical, training and checking up blocks and different interactive elements - Activity book, Recourses, Tests, Glossary and Questionnaire.

Conclusion: According to the given statements lingua-methodic and interactive model for the students' self-training leading in informatics educational medium from the point of view of a module approach are grounded theoretically and checked practically. The main results of the given research are inculcated as in Belgorod Higher Educational Establishments and abroad. It demonstrated its effectiveness during the study of this material by foreign students.
The materials of the present research may be used in the process of creation of electronic student's books, teaching and methodical complexes in Russian for the Chinese and other foreign students mastering the Russian Language or getting education or profession in Russian or in Russia. It may be also used for the purpose of working out lecture courses in computing linguadidactic and then using the materials for those improving their qualification in Methods of Teaching Russian as a Foreign Language.

\section{References}

1. Novikov A.N., Bukalova G.V. The Module Technology as Means of Improvement of Quality of Training in the Higher Education Institution // Standards and Monitoring in Education. 2001. No. 2. Pp. 39-42.

2. Open and Remote Education: Organization, Technology, Quality: materials of the scientific conference. November 27-29, 2001 / Novosibirsk. Novosibirsk: Publishing house of Novosibirsk State Technical University, 2001. $135 \mathrm{p}$.

3. Petrova L.G., Moiseenko O.A. Realization of The Module Approach in Training Foreign Students the Grammatical Aspect of the Speech by Means of Network Technology // Bulletin of the Pomor University. Arkhangelsk, 2007.

4. Yutsyavichene P.A. Theory and Practice of the Module Training. Kaunas: Shviyesa, 1989. 271 p.

5. Analytical Survey Distance Education for the Information Society: Policies, Pedagogy and Professional Development / UNESCO Institute for Information Technologies in Education. M., 2000. 86 p.

6. Bachman L.F. Fundamental Considerations in Language Nesting. Oxford: Oxford University Press, 1990. $408 \mathrm{p}$.

7. Cole J. Using Moodle: teaching with the popular open source course management system. Sebastopol, 2005. $219 \mathrm{p}$.

8. Information and communication technologies in distance education / Specialized training course / Course team chairman Michael G. Moore / UNESCO Institute for information technology in education, 2002.

9. Nunan D. Introducing discourse analysis. - L.: Penguin Books, 1993. 134 p.

10. Richards J.C., Rodgers T.S. Approaches and methods in language teaching: a description and analysis. Cambridge: Cambridge University Press, 1986. 171 p. 